\title{
CALCULATIONS OF LOAD CONTENTS IN THE ROTARY KILN PROCESS AT THE FERRONIKEL PLANT
}

\author{
Zarife Bajraktari-Gashi ${ }^{1}$ \\ Izet Ibrahimi $^{2}$ \\ ${ }^{1}$ University of Mitrovica 'Isa Boletini', Republic of Kosovo, \\ zarife.bajraktari-gashi@umib.net \\ ${ }^{2}$ University of Mitrovica 'Isa Boletini', Republic of Kosovo, \\ izet.ibrahimi@umib.net
}

\begin{abstract}
In this paper, we will calculate the load content in the process of rotary kilns, the thermal quantity of the content of calcine components in rotary kilns during the frying process, electricity consumption - melting of calcine on electric furnace I, for ton calcine of ferronickel in Drenas.
\end{abstract}

The nickel ore is frying in a rotary kiln where a partial reduction of iron-nickel is achieved.

Fuels used as an energy source in the process of rotary kilns:

Kosovo lignite,

$>$ Coal from Indonesia,

$>$ Coal from Russia,

$>$ Coal from Montenegro

$>\quad$ Fuel oil and pet-coke

During the industrial research at the Ferronikeli Plant in Drenas, we have ascertained that the maximum calcine temperature at the outlet of the rotary kilns is $700^{\circ} \mathrm{C}$, during the analysis of the work.

Insufficient processing of iron-nickel ore for rotary kilns causes major problems in not reaching the temperatures inside the kilns, where the high humidity of iron-nickel ore causes great difficulties in the process of frying in rotary kilns.

Because of not achieving high temperatures in rotary kilns, the preparation of the calcine for electric furnace does not reach the proper preparation.

The amount of calcine during 2016 that entered the electric furnace was 291919.64 tons, the amount of energy consumed for melting calcine in electric furnace, reached $553.42 \mathrm{kWh} / \mathrm{t}$ calcine, while the amount of electricity consumed was $57.92 \mathrm{MWh}$ $/ \mathrm{t} \mathrm{Ni}$.

Keys words: Calcine rotary kiln, plant, lignite etc.

2) Technical and Technological Sciences

\section{INTRODUCTION}

At the Ferronickel Plant in Drenas, the load of rotary kilns, in addition to ores from Kosovo, also consists of a large number of imported ores.

Starting from:

- Fe-Ni ores from Indonesia

- Fe-Ni ores from the Philippines

- $\mathrm{Fe}-\mathrm{Ni}$ ores from Macedonia

- Fe-Ni ores from Turkey

- Fe-Ni ores from Guatemala

- Ores from Fe-Ni from Albania

- Ni concentrate from Taiwan. 
All Fe-Ni ores that make up the load of the rotary kilns at the Ferronickel Plant in Drenas as locative and imported are laterite-oxide sources.

Characteristic of most imported ores is the high percentage of moisture as very important factors in the process of rotary kilns and the percentage of $\mathrm{Ni}$ as important factors in the process of nickel metal formation and interest of the process of production of $\mathrm{Fe}$ - alloy $\mathrm{Ni}$.

It is characterized by high $\mathrm{Ni}$ content where the annual average ranges from 2-3\% $\mathrm{Ni}$ while the percentage of moisture is up to $40 \%$ in the composition of ores.

The high moisture content is a very big problem of the realization of the frying process in rotary kilns-the production of frying has in many difficulties during the process, as Fe-Ni ore does not drying before entering the rotary kilns and the ore of iron-nickel in the kiln process zones fails to transform the shapes as predicted in the three rotary kiln process zones.

A special feature is the composition of iron-nickel ores of Albania as they have a low percentage of moisture (11\%) and a high composition of iron oxides. The composition of iron oxides has a reducing effect on the composition of the rotary kiln.

\section{METHODOLOGY}

For the analysis of the load content calculations of the rotary kilns we used mathematical calculations based on industrial and laboratory data. For the calculation of the heat load of the rotary kilns we are based on the composition of the calcine from the rotary kiln, as the main source of information, and the daily amount of calcine spent.

During the industrial research we have ascertained that the maximum temperature of the calcine at the outlet of the rotary kilns during 2016 was $700{ }^{\circ} \mathrm{C}$, and the heat content of the calcine during the calculations will be realized at this temperature.

The heat content of nickel is calculated:

Chemical analysis of the calcine shows the content of $\mathrm{Ni}=1.05 \%$, from which in the form of metal in rotary kilns has passed the amount of $0.08 \% \mathrm{Ni}$.

If the residue expressed in the form of oxide we will express with the equation:

$$
\begin{gathered}
N i O=\frac{P . N i_{\text {fergese }}-\text { Sasia e Ni në formë metali } \times M_{N i O}}{M_{N i}} \\
N i O=\frac{0.97 \times 74.7}{58.7}=1.234 \%
\end{gathered}
$$

P.Ni $i_{\text {fergese }}$-represents the amount $\mathrm{Ni}$ in calcine

For the ton we have $0.8 \mathrm{~kg} N i_{m e t}$ and $12,34 \mathrm{~kg}$

Or if we express it in moles:

$$
N i=\frac{0.8}{58.7}=0.013 \mathrm{~mol}
$$




$$
\mathrm{NiO}=\frac{1,234}{74.7}=0.016 \mathrm{~mol}
$$

At a temperature of $700^{\circ} \mathrm{C} \mathrm{Ni}$ met corresponds to the amount of heat $20900 \mathrm{~kJ} / \mathrm{mol}$, while for $\mathrm{Ni}$ oxide (NiO) corresponds to the amount of heat $36784 \mathrm{~kJ} / \mathrm{mol}$ from which we obtain:

The amount of heat it contains:

$$
N i_{m e t}=0.013 \times 20900=271.7 \mathrm{~kJ}
$$

While the amount of heat it contains:

$$
\mathrm{NiO}=0.016 \times 36784=588.5 \mathrm{~kJ}
$$

The amount of heat of Co:

The content of Co in the baked matter (frying) is $0.04 \%$ and when expressed in oxide form is:

$$
\mathrm{CoO}=\frac{P . C o_{f} \cdot x M_{\mathrm{CoO}}}{M_{\mathrm{Co}}}=\frac{0.04 x 74.93}{58.93}=\frac{2.99}{58.93}=0.050 \%
$$

So a ton calcine contains $0.5 \mathrm{~kg}$ of $\mathrm{CoO}$ or we express it in the form of moles:

$$
\mathrm{CoO}=\frac{0.5}{74.9}=0.0067 \mathrm{~mol}
$$

At a temperature of $700{ }^{\circ} \mathrm{C} \mathrm{CoO}$ contains $36366 \mathrm{~kJ} / \mathrm{mol}$, then the amount of heat per $\mathrm{CoO}$ is:

The amount of heat it contains:

$$
\mathrm{CoO}=0.0067 \times 36366=243.65 \mathrm{~kJ}
$$

The amount of heat than Fe.

Iron in fryers comes in three forms:

$>$ Iron metal, $F e_{\text {metal }}=0.13 \%$

$>$ Iron oxide, $\mathrm{FeO}=11.39 \%$

$>$ Magnetit, $\mathrm{Fe}_{3} \mathrm{O}_{4}=14.10 \%$

$$
F e_{m e t}=\frac{1.3}{56}=0.03 \mathrm{~mol}
$$

$$
\begin{aligned}
& \mathrm{FeO}=\frac{113.9}{72}=1.58 \mathrm{~mol} \\
& \mathrm{Fe}_{3} \mathrm{O}_{4}=\frac{141}{232}=0.61 \mathrm{~mol}
\end{aligned}
$$

Metallic iron $\left(F e_{m e t}\right)$ at $700^{\circ} \mathrm{C}$ contains $22154 \mathrm{~kJ} / \mathrm{mol}$

Iron oxide, $\mathrm{FeO}$ ne $700^{\circ} \mathrm{C}$ cantains $36720 \mathrm{~kJ} / \mathrm{mol}$ and $\mathrm{Fe}_{3} \mathrm{O}_{4}$ contains $142120 \mathrm{~kJ} / \mathrm{mol}$, the amounts of heat are:

The amount of heat $F e_{m e t}=0.03 \times 22154=664.62 \mathrm{~kJ}$

The amount of heat $\mathrm{FeO}=1.58 \times 36720=58017.6 \mathrm{~kJ}$ 
The amount of heat $\mathrm{Fe}_{3} \mathrm{O}_{4}=0.61 \times 142120=86693.2 \mathrm{~kJ}$

The amount of heat of $C_{f i x}$. In a ton calcine have $1.2 \mathrm{~kg} \mathrm{C}$ in the mol:

$$
C=\frac{1.2}{12}=0.1 \mathrm{~mol}
$$

At $700{ }^{\circ} \mathrm{C}$ carbon contains $10868 \mathrm{~kJ} / \mathrm{mol}$

The amount of heat $C_{\text {fix }}=0.1 \times 10868=1086.8 \mathrm{~kJ}$

The amount of heat of calcine losses.

Chemical analysis of calcine has shown the amount of calcine losses of $3.03 \%$ which for one ton of calcine is:

Losses of calcine $\frac{30.2}{44}=0.68 \mathrm{~mol}$

At $700{ }^{\circ} \mathrm{C}$ the calcine losses contain $31768 \mathrm{~kJ} / \mathrm{mol}$, from which we have:

Heat quantity of calcine losses $=0.68 \times 31768=21792.8 \mathrm{~kJ}$

The amount of heat that $\mathrm{SiO}_{2}$. The content of $\mathrm{SiO}_{2}$ in calcine is $46.72 \%$, one ton of calcine contains $467.2 \mathrm{~kg} \mathrm{SiO}_{2}$ or we express it in moles:

$$
\mathrm{SiO}_{2}=\frac{467.2}{60.08}=7.8 \mathrm{~mol}
$$

At $700{ }^{\circ} \mathrm{C} \mathrm{SiO}{ }_{2}$ contains $44308 \mathrm{~kJ} / \mathrm{mol}$, from which we have:

The amount of heat $\mathrm{SiO}_{2}=7.8 \times 44308=345610.2 \mathrm{~kJ}$

The amount of heat $\mathrm{Ca}$. $\mathrm{Ca}$ in calcine is found in two forms: If $\mathrm{CaO}=53.867 \mathrm{t} / 24 \mathrm{~h}$ and if $\mathrm{CaCO}_{3}=288.55 \mathrm{t} / 24 \mathrm{~h}$, that in percentage:

$$
\begin{gathered}
\% \mathrm{CaO}=\frac{53.8967 \times 100}{1633.0}=3.30 \% \\
\% \mathrm{CaCO}_{3}=\frac{288.55 \times 100}{1633.0}=17.66 \%
\end{gathered}
$$

For a calcine tone it is $0.33 \mathrm{~kg} \mathrm{CaO}$ and $176.6 \mathrm{~kg} \mathrm{CaCO}_{3}$ or expressed in mol:

$$
\begin{gathered}
\mathrm{CaO}=\frac{33}{56.08}=0.588 \mathrm{~mol} \\
\mathrm{CaCO}_{3}=\frac{176.6}{100}=0.047 \mathrm{~mol}
\end{gathered}
$$

The amount of heat of $\mathrm{CaO}$ at $700^{\circ} \mathrm{C}$ is $32604 \mathrm{~kJ} / \mathrm{mol}$, while for $\mathrm{CaCO}_{3}$ it is $64790 \mathrm{~kJ} / \mathrm{mol}$, from which we have:

The amount of heat $\mathrm{CaO}=0.588 \times 32604=19171.15 \mathrm{~kJ}$

The amount of heat $\quad \mathrm{CaCO}_{3}=1.765 \times 64790=114354.35 \mathrm{~kJ}$ 
The amount of heat magnesium (Mg)- Magnesium in calcine is found in two forms as: $\mathrm{MgO}=27.1125 \mathrm{t} / 24 \mathrm{~h}$ and $\mathrm{MgCO}_{3}$ of $56.71 \mathrm{t} / 24 \mathrm{~h}$ which in percentage is:

$$
\begin{gathered}
\% M g O=\frac{27.1125 \times 100}{1663.0}=1.62 \% \\
\mathrm{MgCO}_{3}=\frac{56.71 \times 100}{1633.0}=3.471 \%
\end{gathered}
$$

For a calcine tone it is $16.6 \mathrm{~kg} \mathrm{MgO}$ and $34.71 \mathrm{MgCO}_{3}$ if we express it in moles we will have:

$$
\begin{gathered}
\mathrm{MgO}=\frac{16.6}{40.3}=0.412 \mathrm{~mol} \\
\mathrm{MgCO}_{3}=\frac{34.71}{84.3}=0.412 \mathrm{~mol}
\end{gathered}
$$

At a temperature of $700^{\circ} \mathrm{C} \mathrm{MgO}$ and $\mathrm{MgCO}_{3}$ contain $31768 \mathrm{~kJ} / \mathrm{mol}$

We calculate the amount of heat: $M g O=0.412 \times 31768=13056.6 \mathrm{~kJ}$

$$
\mathrm{MgCO}_{3}=0.412 \times 31768=13056.6 \mathrm{~kJ}
$$

\section{DISCUSSION OF RESULTS}

The heat of the calcine at the temperature of $700{ }^{\circ} \mathrm{C}$ is $694440 \mathrm{~kJ} / \mathrm{t}$ calcine.

Since $1 \mathrm{kWh}=3600 \mathrm{~kJ}$ then the heat of calcine $651728 \mathrm{~kJ} / \mathrm{t}$ calcine is equivalent to the electricity consumed of $192.9 \mathrm{kWh} / \mathrm{t}$ calcine.

According to the calculations of the amount of heat we notice that at a temperature of $700^{\circ} \mathrm{C}$ we have electricity savings in the electric furnace affecting $192.2 \mathrm{kWh} / \mathrm{t}$ calcine.

From the calculations of the quantities of heat of the calcine compositions we conclude that during 2016 we spent quantities of heat of $42712 \mathrm{~kJ} / \mathrm{t}$ calcine less in relation to the amount of heat of the calcine at a temperature of

$700{ }^{\circ} \mathrm{C}$. This change in heat quantities comes as a result that during 2016 two rotary kilns have prepared the calcine for only one electric furnace and it has not been worked for six months of 2016.

\section{Recommendations}

- Apply drying for Fe-Ni minerals.

- The amount planned to be equal to the realized amount (ores and fuels). 


\section{LITERATURE}

[1] Z. Bajraktari Gashi(2012)," Theoretical and experimental research in order to reach optimum technical, technologic and productive parameters during qualitative reduction of $\mathrm{Ni}$ ore in $\mathrm{Fe}-\mathrm{Ni}$ foundry in Drenas."PHD, Mitrovica, Republic of Kosovo. November.

[2]Zarife Bajraktari-Gashi, (2021)’Nikeli dhe përfitimi i ferronikelit në Drenas, në proces të botimit, UMIB

[3] Nagip.Murati, (1995), "Metalurgjia e ferronikelit" Tiranë,

[4] Official documentation of smelting complex of NEW FERRONIKELI COMPLEX L.L.C. Gllogoc, years- 2017 -2019 .

[5] Zarife Bajraktari-Gashi, Muharrem Zabeli, Behram Halilaj(2019) "Ndikimi i xeherorëve të Shqipërisë në prodhimin e aliazhit të Fe-Ni në Shkritoren e re të ferronikelit të ri në Drenas." 1sInternational Multidicilplinary Geosciences Conference,(IMGC-2019), 10 -11 Tetor 2019, Mitrovicë,Page, 226-231

[6] Zarife Bajraktari-Gashi, Muharrem Zabeli, Behram Halilaj.(2020) "Key Metallurgical Parameters of Fe-Ni Production During 1984-1997 and 2007-2017 at the Ferronickel Smelter in Drenas" Materials and Geoenvironment.

[7] Z. Bajraktari-Gashi, M. Zabeli, B. Halilaj,(2018)"The impact of pet-kok in the technological process of production of Fe-Ni in the new foundry of the new Ferronikel in Drenas". Journal Int. Environ.\& Sci Vol.13.

[8] Zarife Bajraktari-Gashi, Behram Halilaj, 2020, "Transformimet fazore të mineralit të hekur-nikelit në furra rrotulluese në Uzinën e Ferronikelit.” 2ndINTERNATIONAL MULTIDICILPLINARY GEOSCIENCES CONFERENCE(IMGC-2020) 